\title{
Penanaman Karakter melalui Pembelajaran Sejarah dengan Paradigma Konstruktivistik dalam Kurikulum 2013
}

\author{
HENDRA KURNIAWAN \\ Prodi Pendidikan Sejarah Universitas Sanata Dharma Yogyakarta \\ e-mail : hendrayang7@gmail.com
}

\begin{abstract}
Abstrak
Perubahan kurikulum semestinya diikuti dengan perubahan dalam proses pembelajaran. Pembelajaran sejarah disadari memiliki fungsi yang penting dan strategis untuk menanamkan kesadaran sejarah dan membangun karakter bangsa. Pembelajaran sejarah berdasarkan Kurikulum 2013 hendaknya tidak lagi berorientasi pada materi ajar, namun lebih pada pengalaman belajar yang dilakukan oleh peserta didik. Pembelajaran sejarah harus lebih hidup dan bermakna. Implementasi kurikulum 2013 dalam pembelajaran sejarah dilakukan dengan menerapkan paradigma konstruktivistik. Peserta didik sebagai subjek belajar mencari tahu dan menggali pengetahuan secara mandiri serta mengembangkan kemampuan dengan maksimal untuk menemukan nilai dan makna dari suatu peristiwa sejarah. Pembelajaran konstruktivistik dapat dilaksanakan melalui strategi pembelajaran inkuiri, kontekstual, dan kooperatif yang didukung dengan pemanfaatan teknologi informasi dan komunikasi sebagai sumber sekaligus media dan sarana belajar. Melalui pembelajaran sejarah yang konstruktivistik maka penanaman karakter dapat dilakukan dengan lebih mudah dan bermakna.
\end{abstract}

Kata kunci: pembelajaran sejarah, konstruktivistik, karakter, kurikulum 2013

\begin{abstract}
Curriculum changes should be followed by changes in the learning process. Learning history has recognized the important and strategic functions to instill history awareness and build the character of the nation. Learning history based Curriculum 2013 should no longer oriented teaching material, but rather on learning experience carried out by student. Learning history should be more vibrant and meaningful. Implementation of curriculum 2013 in the teaching of history is done by applying constructivist paradigm. The student as a subject of study to find out and explore on their own knowledge and develop the ability to find value and the significance from a historical event. Constructivist learning strategies can be implemented through inquiry, contextual, and cooperative learning whiches supported by the use of information and communication technology as well as the source, media, and learning tools. History constructivist learning make the cultivation of character can be done more easily and meaningfully.
\end{abstract}

Keywords: learning history, constructivist, character, curriculum 2013 


\section{PENDAHULUAN}

Pendidikan memegang peran penting bagi perkembangan dan kemajuan negara. Keberadaan dan keberlangsungan suatu negara ditentukan oleh kualitas generasi penerusnya. Melalui pendidikan generasi penerus memperoleh kesempatan untuk menumbuhkembangkan kemampuan dan kepribadiannya. Pendidikan menurut taksonomi Bloom memiliki tujuan yang kompleks namun sangat mulia yaitu mengembangkan kemampuan peserta didik yang mencakup pengetahuan (kognitif), sikap (afektif), dan keterampilan (psikomotorik/skill). Semua ini dapat dicapai melalui aktivitas dan pengalaman belajar. Dengan demikian pendidikan membutuhkan seperangkat komponen yang disebut kurikulum agar dapat mengarahkan pendidikan menuju arah dan tujuan yang dimaksudkan dalam kegiatan pembelajaran secara menyeluruh.

Didasari oleh keberadaan kurikulum yang vital bagi kemajuan pendidikan maka pembaruan-pembaruan kurikulum memang diperlukan. Perubahan kurikulum dan pendekatan pembelajaran harus dipahami sebagai kebutuhan. Dinamika zaman dan masyarakat memang menuntut terjadinya perubahan kurikulum agar dapat meningkatkan kualitas proses dan output dari pendidikan. Akan tetapi dalam praktiknya ketika terjadi perubahan kurikulum ternyata proses pembelajaran yang dilakukan seringkali luput untuk disesuaikan. Upaya untuk mengubah paradigma dan cara pandang pembelajaran yang baru agar seiring dengan perubahan kurikulum bukanlah hal yang mudah. Seringkali sudah terlalu nyaman dengan cara-cara yang biasa, maka ide baru tidak mendapat tempat, sehingga peningkatan kualitas pendidikan yang diharapkan tidak tercapai.

Satu hal yang perlu dipahami bahwa kurikulum yang disusun sebenarnya memiliki tujuan masing-masing. Dengan demikian setiap kurikulum dihidupi oleh rohnya yang khas. Keprihatinan terhadap merosotnya moral bangsa dan pentingnya pembangunan karakter menjadi landasan bagi penyusunan
Kurikulum 2013. Dalam kerangka pendidikan karakter, sejarah dianggap sebagai salah satu mata pelajaran yang memiliki potensi besar sebagai sarana penanaman karakter kebangsaan bagi peserta didik. Pembelajaran sejarah semestinya tidak hanya membicarakan peristiwa-peristiwa masa lampau saja yang menuntut siswa untuk menghapal materi yang luar biasa banyaknya. Menyitir ung kapan Cicero, Historia Magistra Vitae, maka sejarah hendaknya dapat menanamkan nilainilai hidup, kesadaran sejarah, dan rasa kebangsaan bagi generasi muda.

Menyadari peran penting dari belajar sejarah bagi generasi muda maka pembelajaran sejarah sesuai Kurikulum 2013 sudah seharusnya jauh dari pola konvensional yang berpusat pada guru dan materi. Diperlukan pendekatan baru dalam pembelajaran sejarah agar roh yang menghidupi Kurikulum 2013 tidak lantas mati. Pendekatan yang paling tepat agar tidak membunuh jiwa Kurikulum 2013 ialah melalui pembelajaran sejarah yang konstruktivistik. Melalui pembelajaran kontruktivistik maka peserta didik memiliki kesempatan untuk memperoleh pengalaman belajar yang lebih luas. Dari situ diharapkan peserta didik mampu menggali lebih dalam nilai-nilai karakter yang diperoleh dari aktivitas belajarnya tersebut.

\section{PERKEMBANGAN KURIKULUM DI INDO- NESIA}

Kurikulum pada awalnya lebih sering diartikan sebagai kumpulan mata pelajaran (subject matter) yang harus ditempuh oleh peserta didik. Paradigma lama tentang kurikulum ini bukanlah sesuatu yang keliru. Pada kenyataannya kurikulum memang tersusun atas sejumlah mata pelajaran tertentu yang harus diterima dan dikuasai oleh peserta didik agar dapat dinyatakan lulus dari suatu satuan pendidikan. Paradigma lama ini perlu diubah.

Oemar Hamalik (2011: 4) mengungkapkan pendapat Romine mengenai paradigma baru yang modern tentang kurikulum yaitu bahwa kurikulum tidak hanya terdiri dari 
mata pelajaran, namun juga kegiatan dan pengalaman belajar. Untuk mengimplementasikan hal ini dengan baik, diperlukan berbagai pendekatan dan model pembelajaran yang bervariasi. Guru juga harus menggunakan berbagai metode dan inovasi pembelajaran yang lebih segar dan kreatif.

Kurikulum terdiri atas materi ajar dan berbagai pengalaman belajar yang diperlukan peserta didik demi tercapainya tujuan pendidikan. Seringkali terjadi berbagai kesulitan dalam menyusun dan merencanakan kurikulum yang relevan dengan tujuan yang hendak dicapai. Hal ini disebabkan dinamika masyarakat yang senantiasa berubah dan berkembang.

Sejak kemerdekaannya, Indonesia sudah mengalami beberapa kali perubahan kurikulum. Pada tahun 1947 sebagai peletak dasar kurikulum nasional disusunlah Rencana Pelajaran (Leer Plan) yang merinci uraian-uraian pelajaran yang harus ditempuh oleh peserta didik. Sebagai peralihan dari pendidikan ala kolonial ke pendidikan nasional, maka kurikulum ini juga banyak menanamkan kesadaran berbangsa dan bernegara. Rencana Pelajaran ini disempurnakan melalui Rencana Pendidikan 1964. Kebijakan ini arahnya ialah memberikan bekal akademik yang cukup bagi anak usia sekolah dasar.

Pasca Peristiwa 1965 muncullah Kurikulum 1968 yang menekankan pada pembinaan jiwa pancasila, pengejawantahan pelaksanaan UUD 1945 secara murni dan konsekuen, pengetahuan dasar, dan kecakapan khusus. Kurikulum 1968 merupakan kurikulum yang pertama kali terintegrasi dengan munculnya mata pelajaran Ilmu Pengetahuan Sosial (IPS) dan Ilmu Pengetahuan Alam (IPA).

Mulai berakarnya kekuasaan Orde Baru yang menyatakan diri sebagai Orde Pembangunan juga berpengaruh terhadap kebijakan penyusunan kurikulum. Tahun 1973 dicetuskan Proyek Perintis Sekolah Pembangunan (PPSP). Seiring dengan ide tersebut dan keinginan pemerintah menciptakan pendidikan yang lebih efektif dan efisien maka lahirlah Kurikulum 1975. Dalam Kurikulum 1975 disusun Prosedur Pengembangan Sistem
Instruksional (PPSI) yang berisi metode, materi, dan tujuan pengajaran berdasarkan pada Garis-garis Besar Program Pengajaran (GBPP).

Perkembangan iptek yang luar biasa berpengaruh semakin besar bagi kehidupan masyarakat. Atas dasar inilah dipandang perlu untuk mengadakan perubahan kurikulum yang berbasis iptek. Pada tahun 1984 diadakan penyempurnaan kurikulum 1975. Kurikulum 1984 tetap berorientasi utama pada tujuan namun menggunakan pendekatan keterampilan proses (process skill approach). Siswa ditempatkan sebagai subjek belajar. Pendekatan ini lebih populer disebut dengan istilah CBSA (Cara Belajar Siswa Aktif) atau SAL (Student Active Learning). Dalam pembelajaran CBSA, siswa diajak untuk mengamati, mengelompokkan, mendiskusikan, dan mela porkan apa yang dipelajarinya.

Dalam Kurikulum 1984 ini, pelajaran sejarah dan guru sejarah sempat menjadi "bintang" dalam pendidikan nasional. Menteri Pendidikan dan Kebudayaan saat itu, Nugroho Notosusanto, adalah seorang sejarawan militer Orde Baru. Atas dasar nasionalisme yang tinggi dan keyakinannya terhadap Orde Baru, beliau merasa bahwa pendidikan harus mendukung pembangunan di segala bidang dan sebagai manusia pembangunan maka anak didik harus memiliki jiwa patriotisme. Sekolah-sekolah mengajarkan mata pelajaran baru di samping mata pelajaran sejarah yaitu Pendidikan Sejarah Perjuangan Bangsa (PSPB).

Sepuluh tahun kemudian kembali diadakan pembaruan kurikulum yang berbasis budaya bangsa. Kurikulum 1994 ini berupaya mengkombinasikan kurikulum sebelumnya yaitu Kurikulum 1975 yang berorientasi sepenuhnya pada tujuan dan Kurikulum 1984 dengan pendekatan keterampilan proses. Kurikulum 1994 mulai memperkenalkan adanya muatan lokal. Materi muatan lokal disesuaikan dengan kekhasan daerah masing-masing, seperti bahasa daerah, kesenian dan keterampilan daerah, hingga kebutuhan masyarakat seperti tata kota dan lingkungan hidup. Beban belajar dalam Kurikulum 1994 menjadi 
sangat berat karena berorientasi pada isi materi (content oriented). Runtuhnya rezim Soeharto pada tahun 1998 kemudian diikuti oleh munculnya Suplemen Kurikulum 1999. Akan tetapi suplemen ini tidak mengadakan perubahan pada isi materi kurikulum, namun sekedar merevisi dan mengurangi beban sejumlah materi.

Kurikulum 1975, 1984, dan 1994 me nganut teori behavioristik yang menekan kan pada pencapaian tujuan tanpa memperhatikan proses yang berlangsung. Menurut teori ini, pembelajaran lebih dilihat sebagai hubungan antara stimulus dan respon sehingga diperlukan kondisi dan stimulus yang baik untuk menciptakan respon (hasil) dari peserta didik (Dale H. Schunk, 2012: 100). Meskipun menggunakan pendekatan kete rampilan proses namun kenyataannya orientasi tujuan dan padatnya materi membuat proses menjadi dikesampingkan. Implikasi nya ialah penguasaan ranah kognitif menjadi lebih dominan daripada penguasaan kete rampilan (skill). Kondisi ini membuat lulusan tidak memiliki kemampuan yang memadai dalam menghadapi persaingan kerja yang semakin ketat. Untuk itulah pada tahun 2004, seiring dengan kemajuan zaman yang semakin pesat disusun Kurikulum Berbasis Kompetensi yang berorientasi pada penguasaan kompetensi-kompetensi secara holistik agar dapat memperoleh kecakapan hidup (life skill).

KBK mulai diujicobakan pada tahun 2004, namun dianggap kurang berhasil. Pada tahun 2006 KBK disempurnakan menjadi Kurikulum Tingkat Satuan Pendidikan (KTSP). Jika KBK disusun oleh Tim Pusat secara rinci sehingga cenderung terjadi sentralisasi pendidikan, maka KTSP lebih memberikan kebebasan pada guru untuk merencanakan pembelajaran sesuai dengan kondisi siswa, sekolah, dan lingkungan. Setiap satuan pendidikan memiliki kewenangan untuk mengembangkan KTSP secara mandiri. Dalam KTSP materi pelajaran lebih sedikit namun jumlah jam banyak. Hal ini bertujuan untuk mendukung pencapaian kompetensi. Menurut Piaget dalam Dale H. Schunk (2012: 336), pembelajaran kognitif dilaku- kan dengan cara menjaga agar peserta didik tetap bereksplorasi secara aktif, membiarkan peserta didik mencari jawaban terhadap persoalan yang ditemukannya, dan menciptakan agar peserta didik berinteraksi dengan siapa saja dalam belajar.

Kementerian Pendidikan dan Kebuda yaan (2013: 1-2) mengungkapkan hasil evaluasi Badan Standar Nasional Pendidikan (BSNP) terhadap KTSP disimpulkan di antaranya bahwa: (1) Konten kurikulum masih terlalu padat. ; (2) Kompetensi belum menggambarkan secara holistik domain sikap, keterampilan, dan pengetahuan; (3) Belum terakomodasinya pendidikan karakter, metodologi pembelajaran aktif, keseimbangan soft skills dan hard skills, kewirausahaan; (4) Kurikulum belum peka dan tanggap terhadap perubahan sosial yang terjadi pada tingkat lokal, nasional, maupun global; (5) Proses pembelajaran belum digambarkan secara rinci sehingga membuka peluang penafsiran yang beraneka ragam dan berujung pada pembelajaran yang berpusat pada guru.

Menurut Kementerian Pendidikan dan Kebudayaan (2013: 2), KTSP dikembangkan menjadi Kurikulum 2013 dengan dilandasi pemikiran tantangan masa depan yaitu tantangan abad XXI yang ditandai dengan abad ilmu pengetahuan, knowledge-based society, dan kompetensi masa depan. Maka Kurikulum 2013 masih berpijak pada penca paian kompetensi-kompetensi tertentu yang diharapkan, namun aktivitas peserta didik dalam proses pembelajaran lebih diperhatikan. Pengalaman belajar sangat diperlukan dalam rangka mencapai tiga kompetensi penting yang ditekankan yaitu membentuk sikap, mengembangkan keterampilan, dan membangun pengetahuan.

\section{SUBSTANSI KURIKULUM 2013}

Kurikulum 2013 merumuskan tiga kompetensi utama yaitu attitude, skill, dan knowledge (ASK) dengan prioritas dan penekanan yang berbeda-beda pada setiap jenjang pendidikan. Peserta didik di SD diarahkan pada pembentukan sikap (attitude), SMP pada ranah keterampilan (skill), dan SMA dipenuhi 
dengan mata pelajaran untuk membangun pengetahuan (knowledge).

Dalam Kurikulum 2013 diadakan penyederhanaan mata pelajaran. Capaian kompetensi diperoleh melalui proses pembelajaran dari berbagai kompetensi dasar yang diorganisasikan oleh kompetensi inti. Setiap mata pelajaran memiliki kompetensi inti yang sama. Ada empat kompetensi inti yang dirumuskan yaitu sikap spiritual, sikap sosial, pengetahuan, dan keterampilan. Kelompok kompetensi dasar sikap spiritual dan sikap sosial tidak diujikan namun dijadikan pegangan bahwa dalam pembelajaran di setiap mata pelajaran terdapat pesan spiritual dan sosial. Proses pembelajaran dimulai dengan kompetensi pengetahuan, keterampilan, dan berakhir pada pembentukan sikap.

Sesuai dengan Kurikulum 2013, pada jenjang SD, mata pelajaran disajikan secara tematik. Hal ini didasari oleh pemikiran bahwa anak usia SD cara berpikirnya masih holistik belum spesifik. Pada kelas I-III SD, mata pelajaran IPA dan IPS diintegrasikan dengan mata pelajaran Bahasa Indonesia, Matematika, dan PKn.

Pada jenjang SMA tidak digunakan lagi istilah penjurusan, namun yang dipakai ialah peminatan. Sesuai dengan penekanannya untuk membangun pengetahuan, maka peserta didik di SMA diberi kesempatan seluasluasnya untuk mengembangkan minat dan kemampuannya. Peserta didik sejak SMA kelas $\mathrm{X}$ diberi kebebasan untuk memilih mata pelajaran pilihan yang sesuai dengan minat, bakat, dan kemampuannya. Diharapkan peserta didik benar-benar memiliki kemampuan pada suatu disiplin ilmu atau keteram pilan tertentu yang akan ditekuninya pada jenjang perguruan tinggi. Ada tiga kelompok peminatan yaitu Matematika dan Ilmu-ilmu Alam, Ilmu-ilmu Sosial, dan Ilmu-ilmu Bahasa dan Budaya.

Mata pelajaran Teknologi Informasi dan Komunikasi (TIK) yang belum lama ini dirintis dihapuskan. TIK dianggap tidak perlu lagi dijadikan mata pelajaran yang berdiri sendiri karena di era global sekarang ini, TIK sudah semestinya digunakan dalam setiap mata pelajaran sebagai alat atau media pembelajaran. Semua guru dituntut untuk dapat memanfaatkan TIK dalam aktivitas pembelajaran yang diorganisasikannya. Demikian pula dengan mata pelajaran bahasa daerah juga dihilangkan, namun tetap dapat diberikan melalui mata pelajaran seni budaya.

Dalam rangka mencapai pembentukan sikap (attitude), meningkatkan keterampilan (skill), dan membangun pengetahuan (knowledge) maka perlu perubahan pula dalam kegiatan evaluasi. Peserta didik diarahkan agar kemampuan berpikir kritisnya berkembang, memiliki kreativitas, terampil, dan dapat menunjukkan sikap yang baik melalui berpendapat dan mengungkapkan komitmen. Kegiatan evaluasi hendaknya tidak menyajikan bentuk pertanyaan atau soal-soal yang mengarah pada jawaban konvergen. Soal berbentuk pilihan ganda, benarsalah, menjodohkan, dan sejenisnya akan menumpulkan kemampuan berpikir kritis dan mematikan kreativitas. Jauh lebih tepat apabila kegiatan evaluasi dilakukan dengan memberikan soal-soal yang terbuka dan memungkinkan muncul banyak kemungkinan jawaban (divergen).

\section{PERAN PEMBELAJARAN SEJARAH DALAM MEMBANGUN KARAKTER}

Dalam hasil evaluasi BSNP terhadap KTSP seperti telah dijelaskan sebelumnya bahwa salah satu yang menjadi keprihatinan ialah belum terakomodasinya pendidikan karakter yang saat ini menjadi kebutuhan mendesak. Sosok pemimpin bangsa mulai jauh dari keteladanan, korupsi mengakar kuat merambah setiap ranah kekuasaan termasuk aparat penegak hukum itu sendiri, rendahnya rasa toleransi dan sikap saling menghormati, merasuknya jiwa individualis, dan budaya kekerasan telah menjadi wabah endemi. Ini menjadi indikator merosotnya mental dan karakter bangsa yang konon Pancasilais.

Pendidikan dapat menjadi sarana utama dalam penanaman karakter. Ada hubungan yang erat antara sejarah dengan pendidikan karakter. Kesadaran sejarah akan membawa seseorang mengenal diri sendiri se 
bagai bangsa (self understanding of nation) dan memahami kehidupan bangsa. Menurut Aman (2011: 14-15), sejarah memiliki fungsi dapat mengajarkan manusia (man of action) tentang bagaimana orang lain bertindak dalam keadaan-keadaan khusus, menentukan pilihan-pilihan yang dibuatnya, dan tentang keberhasilan atau kegagalan mereka. Sejarah menjelaskan kondisi dan situasi yang tepat bagi seorang negarawan dalam melaksanakan tugas kenegaraannya secara tepat pula. Sejarah membentuk manusia menjadi lebih bijaksana dan berkarakter (wise man).

Aman (2011: 31-32, 35) juga menjelaskan bahwa sejarah dapat menanamkan kesadaran persatuan, persaudaraan, dan solidaritas sebagai perekat bangsa dalam menghadapi ancaman disintegrasi bangsa, sarat dengan ajaran moral dan kearifan yang berguna dalam mengatasi krisis multidimensional yang dihadapi dalam kehidupan sehari-hari. Materi sejarah mengandung nilai-nilai kepahlawanan, keteladanan, kepeloporan, patriotisme, nasionalisme, dan semangat pantang menyerah yang mendasari proses pembentukan watak dan kepribadian peserta didik.

Dalam kurikulum 2013 beberapa kompetensi dasar dikemas dalam naungan empat kompetensi inti yang tidak hanya menekan kan aspek kognitif saja, namun juga sikap spiritual, sikap sosial, dan keterampilan. Hal ini tentu semakin memberi ruang bagi mata pelajaran sejarah untuk berperan serta dalam pembentukan kesadaran sejarah dan pembangunan karakter bangsa (nation character building).

Penekanan capaian yang diharapkan dalam Kurikulum 2013 sejalan dengan pemikiran I Gde Widja (1989: 27-28) yang juga menjelaskan tujuan pembelajaran sejarah yang dapat dipilih sejalan dengan taksonomi Bloom, yang mencakup ranah pengetahuan, sikap, dan keterampilan yang aspek-aspek beserta rinciannya meliputi: ranah pengetahuan: (1) menguasai pengetahuan tentang aktivitas-aktivitas manusia waktu yang lampau baik dalam aspek eksternal maupun internalnya; (2) menguasai pengetahuan tentang fakta-fakta khusus dari peristiwa masa lampau sesuai dengan waktu, tempat, serta kondisi pada waktu terjadinya peristiwa tersebut; (3) mengetahui pengetahuan tentang unsur-unsur umum yang terlihat pada sejumlah peristiwa masa lampau; (4) menguasai pengetahuan tentang unsur perkembangan dari peristiwa-peristiwa masa lampau yang berlanjut yang menyumbangkan peristiwa masa lampau dengan masa kini; (5) menumbuhkan pengertian hubungan antar fakta, keterkaitan fakta, pengaruh sosial dan kultural terhadap peristiwa sejarah atau sebaliknya.

Ranah pengembangan sikap meliputi:

1) menumbuhkan kesadaran sejarah pada murid agar mampu berpikir dan bertindak sesuai dengan tuntutan zaman pada waktu mereka hidup;

2) menumbuhkan sikap menghargai kepentingan atau kegunaan pengalaman masa lampau bagi hidup masa kini suatu bangsa;

3) menumbuhkan sikap menghargai aspek kehidupan masa kini dari masyarakat di mana mereka hidup, yaitu suatu masyarakat hasil dari pertumbuhan di waktu yang lampau;

4) menumbuhkan kesadaran akan perubahan-perubahan yang telah dan sedang berlangsung di suatu bangsa yang diharapkan menuju pada kehidupan yang lebih baik di waktu yang akan datang.

Ranah pengembangan keterampilan meliputi:

1) menekankan pengembangan kemampuan dasar di kalangan murid berupa kemampuan penyusunan sejarah yang antara lain meliputi pengumpulan jejakjejak sejarah, kritik sejarah, interpretasi, serta menulis sejarah sederhana;

2) keterampilan mengajukan argumentasi dalam mendiskusikan masalah-masalah kesejarahan (peranan tokoh dan hubu ngan peristiwa);

3) keterampilan menelaah buku sejarah, bertanya, berpikir analitis tentang masalah-masalah sosial historis di lingku ngan masyarakatnya;

4) keterampilan bercerita tentang peristiwa 
sejarah secara hidup (menghidupkan kembali peristiwa sejarah).

Peran strategis dari mata pelajaran sejarah bagi pembentukan karakter telah ditangkap dengan baik oleh penyusun kurikulum. Dalam Kurikulum 2013, mata pelajaran sejarah mendapat porsi jam yang lebih banyak dibandingkan pada kurikulum sebelumnya. Mata pelajaran sejarah dikelompokkan menjadi dua yaitu mata pelajaran Sejarah Indonesia sebagai kelompok mata pelajaran wajib untuk semua peminatan, dan ditambah mata pelajaran Sejarah khusus untuk peminatan Ilmu-ilmu Sosial. Berbeda dengan mata pelajaran wajib Sejarah Indonesia yang berarti mencakup materi Sejarah Nasional Indonesia saja, maka peserta didik pada peminatan Ilmu Sosial tidak hanya mendapat materi sejarah nasional Indonesia namun juga sejarah dunia.

Sejarah sebagai kelompok mata pelajaran wajib mendapat porsi 2 jam per minggu. Jatah ini tepat agar peserta didik pada semua peminatan benar-benar mendapat kesempatan yang cukup dalam memahami sejarah bangsanya sehingga muncul kesadaran sejarah dan terbangun karakter kebangsaannya. Peserta didik pada peminatan Ilmu-ilmu Sosial berkesempatan lebih untuk mengembangkan pengetahuan dan keterampilannya dalam ilmu sejarah dengan porsi jam yang lebih banyak. Hal ini menjadi indikasi bahwa mata pelajaran sejarah mulai "naik kelas". Keprihatinan para guru, pendidik, maupun pemerhati sejarah, termasuk juga sejarawan yang menyayangkan adanya kesan mata pelajaran sejarah dinomorsekiankan kini telah menemukan secercah harapan.

\section{PEMBELAJARAN SEJARAH YANG KON- STRUKTIVISTIK}

Kurikulum 2013 perlu diimplementasikan secara tepat. Hal ini berarti harus ada perubahan paradigma dalam pembelajaran yang dilakukan, jika tidak maka perubahan kurikulum menjadi sia-sia belaka. Menurut Oemar Hamalik (2011: 237) implementasi merupakan suatu proses penerapan ide, kon- sep, kebijakan, atau inovasi dalam bentuk tindakan praktis sehingga memberikan dampak, baik berupa perubahan pengetahuan, keterampilan, maupun nilai dan sikap. Maka implementasi kurikulum berarti penerapan konsep, ide, program, tatanan, atau aktualisasi kurikulum ke dalam bentuk praktik pembelajaran sehingga terjadi perubahan sikap pada sekelompok orang.

Implementasi kurikulum bukan sekedar penerapan atau pelaksanaan kurikulum pada satuan pendidikan. Implementasi kurikulum diartikan pula sebagai pembelajaran sehingga membutuhkan penyesuaian kondisi di lapangan dan karakteristik peserta didik. Demikian pula terkait dengan pembelajaran sejarah sesuai Kurikulum 2013 tentu sudah seharusnya jauh dari pola konvensional yang berpusat pada guru dan materi.

Pada Kurikulum 2013 sejalan dengan kompetensi inti, maka peserta didik dituntut untuk memiliki keterampilan mengolah, menalar (yang dapat diartikan berpikir kritis), memecahkan masalah, dan pada akhirnya mampu menyajikannya dalam ranah konkret maupun abstrak konsep-konsep keilmuan yang telah didapat sebelumnya. Untuk pencapaian tersebut maka proses pembelajaran dilaksanakan melalui lima tahapan pendekatan scientific yang dimulai dari mengamati, menanya, menalar, mencoba, dan membuat jaringan (berkolaboratif).

Implementasi kurikulum 2013 harus dicari berbagai alternatif pembelajaran sejarah dengan paradigma baru. Selain nantinya diperlukan berbagai macam strategi dan metode dalam praktiknya, namun yang pertama-tama harus diubah ialah pendekatan yang digunakan. Wina Sanjaya (2010: 127) menjelaskan bahwa pendekatan (approach) dalam pembelajaran dapat diartikan sebagai titik tolak atau sudut pandang terhadap pro ses pembelajaran.

Menurut Roy Killen dalam Wina Sanjaya (2010: 127) ada dua pendekatan pembelajaran yaitu berpusat pada guru (teacher centered approach) dan berpusat pada siswa (student centered approach). Dalam kaitannya dengan implementasi kurikulum 2013 yang mementingkan proses, maka pendeka- 
tan yang paling tepat adalah berpusat pada siswa sebagai subjek belajar. Terkait dengan pendekatan ini maka konstruktivisme menjadi teori yang paling tepat digunakan dalam praktik pembelajaran.

John W. Santrock (2007: 389) menjelaskan bahwa "konstruktivisme merupakan pendekatan untuk pembelajaran yang menekankan bahwa individu akan belajar dengan baik apabila mereka secara aktif mengkonstruksi pengetahuan dan pemahaman". Atas pemikiran inilah proses pembelajaran seharusnya dapat memberikan ruang bagi siswa untuk aktif dan menjadi pusat kegiatan pembelajaran di kelas. Guru dapat memfasilitasi dengan menggunakan caracara yang membuat informasi menjadi bermakna dan relevan bagi siswa.

Vygotsky menekankan bahwa siswa mengkonstruksi pengetahuan melalui inte raksi sosial dengan orang lain. Maka ditekan kan guru harus menciptakan banyak kesempatan bagi siswa untuk belajar dengan guru dan teman sebaya dalam mengkonstruksi pengetahuan bersama. (John W. Santrock, 2007: 390).

Pembelajaran sejarah yang konstrukti vistik diperlukan untuk membangkitkan keaktifan dan kreatifitas, salah satunya dengan memberi kesempatan peserta didik untuk menyajikan hasil analisis, mendiskusikannya, dan mengambil makna dari suatu peristiwa sejarah. Peserta didik juga diajak berpikir kritis melalui sudut pandang sejarah untuk menarik benang merah dari berbagai masalah bangsa saat ini dan kemudian mencoba mencari solusinya dalam koridor wawasan kebangsaan.

Pembelajaran konstruktivistik dapat dilakukan dengan berbagai strategi dan metode misalnya inkuiri, kontekstual, dan kooperatif. Hal ini dapat diterapkan pula melalui tahapan-tahapan pendekatan scientific. Strategi pembelajaran inkuiri yaitu pembelajaran yang menekankan pada proses berpikir secara kritis dan analitis untuk mencari dan menemukan sendiri jawaban dari suatu masalah yang dipertanyakan (Wina Sanjaya, 2010: 196). Inkuiri dalam pembelajaran sejarah dapat dilakukan mulai dari tahapan mengamati berbagai sumber belajar yang ada entah itu penjelasan guru, buku, televisi, koran, internet, media audio visual, pelaku atau saksi sejarah, hingga pengamatan terhadap benda peninggalan sejarah. Guru hendak nya meminta peserta didik mencatat ber bagai hal-hal baru yang ditemukan tersebut. Barangkali ada beberapa hal yang menyimpang dari konteks materi namun sebenarnya tidak menjadi masalah sepanjang dapat menjadi pengetahuan tambahan bagi peserta didik secara keseluruhan. Pertanyaan dan halhal baru ini kemudian diolah dalam tahapan menanya.

Dari kegiatan tersebut maka peserta didik dapat mengembangkan pemikirannya dan menemukan hubungan antara materi yang dipelajari dengan situasi kehidupan nyata saat ini. Inilah yang disebut dengan pembelajaran kontekstual sebagai bagian dari gagasan konstruktivistik. Menurut Wina Sanjaya (2010: 255) pembelajaran konteks tual atau Contextual Teaching and Learning (CTL) mendorong siswa menemukan hubu ngan antara pengalaman belajar di sekolah dengan kehidupan nyata dan kemudian dapat menerapkannya dalam kehidupan. Hal ini penting karena dengan mengorelasikan materi yang ditemukan dengan kehidupan nyata, maka materi yang dipelajari akan tertanam erat dan tidak mudah dilupakan.

Salah satu contoh penerapan CTL misalnya pada materi peristiwa sekitar Proklamasi 17 Agustus 1945. Peserta didik diberi tugas mencari berbagai peristiwa sekitar kemerdekaan dari munculnya perbedaan pendapat soal penyusunan dasar negara hingga konflik antara golongan tua dengan golongan muda yang disajikan dalam bentuk media powerpoint dilengkapi dengan gambar-gambar. Peserta didik dapat mengambil makna dan nilai tertentu dari berbagai peristiwa sejarah tersebut. Hal yang dapat dipetik ialah meskipun muncul berbagai perbedaan pendapat namun dapat diselesaikan dengan baik dan kemerdekaan dapat tercapai karena adanya kebesaran hati dalam menerima berbagai perbedaan, adanya sikap toleransi, saling menghargai, mementingkan kepentingan bersama yang 
lebih besar, eratnya persatuan dan kesatuan, dan tingginya rasa kebangsaan. Nilai-nilai ini dapat dikaitkan dengan kondisi bangsa saat ini yang mengalami kemerosotan sikap untuk saling menghargai dan menerima perbedaan, kurangnya toleransi akibat menonjolkan kepentingan pribadi atau kelompoknya saja, adanya sikap esktrimis suatu kelompok yang menyudutkan kelompok lain, dan pudarnya rasa kebangsaan serta persatuan dan kesatuan. Inilah yang dalam pendekatan scientific digolongkan dalam kegiatan menalar sekaligus dapat digunakan untuk menggali sikap sosial dari peserta didik.

Tahapan mencoba dapat dilakukan misalnya dengan memberikan tugas berupa proyek kepada peserta didik baik secara individu maupun kelompok. Proyek tersebut dapat berupa menyusun laporan, membuat artikel atau makalah, mencari video tentang peninggalan bersejarah, dokumenter tentang suatu peristiwa sejarah, menyusun media pembelajaran sejarah dalam bentuk powerpoint atau kumpulan gambar, hingga membuat drama sejarah yang hasilnya direkam menggunakan kamera rekorder. Pada tahapan ini keterampilan dan kreativitas peserta didik dapat lebih dikembangkan.

Interaksi peserta didik dalam pembelajaran konstruktivistik tidak hanya terjadi antara peserta didik dengan sumber belajar atau media pembelajaran saja. Dalam berbagai aktivitas yang sejalan dengan tujuan konstruktivisme, maka pembelajaran menekankan pula berbagai bentuk interaksi antar peserta didik sehingga muncul suatu komunitas pembelajar. Dalam komunitas pembelajar inilah peserta didik perlu didorong untuk saling bertukar pandangan melalui diskusi kelas yang rutin (Jeanne Ellis Ormrod, 2008: 352). Dalam Kurikulum 2013 kegiatan ini termasuk dalam tahapan terakhir yaitu membuat jaringan (kolaboratif).

Melalui kegiatan melaporkan atau mempresentasikan hasil proyek yang telah dibuat oleh peserta didik maka guru dan peserta didik dapat saling menukar informasi. Antar peserta didik juga dapat saling memberikan penjelasan mengenai tema atau pokok bahasan dari tugas proyek yang dilakukannya masing-masing.

Penerapan konstruktivisme dalam pembelajaran menghasilkan metode pengajaran yang menekankan aktivitas utama pada peserta didik. Teori pembelajaran konstruktivisme memandang murid sebagai orang yang menanggapi secara aktif objek-objek dan peristiwa dalam lingkungannya, serta memperoleh pemahaman tentang seluk beluk objek-objek dan peristiwa itu. Peserta didik merupakan subjek utama dalam kegi atan penemuan pengetahuan yang disusun melalui berbagai pengalaman yang memungkinkan terbentuknya pengetahuan.

Meskipun dalam pandangan konstruktivisme upaya membangun pengetahuan dilakukan oleh peserta didik melalui kegiatan belajar yang ia lakukan, namun peran guru tetap menempati arti penting dalam proses pembelajaran. Mengajar tidak sekedar menyampaikan informasi, tetapi lebih menitikberatkan sebagai mediator dan fasilitator (Paul Suparno, 1997: 66). Tugas guru sebagai mediator dan fasilitator dijabarkan sebagai berikut:

- Menyediakan pengalaman belajar yang memungkinkan peserta didik bertanggung jawab dalam membuat rancangan, proses, dan penelitian.

- Memberikan kegiatan yang merangsang keingintahuan peserta didik dan membantu peserta didik mengekspresikan gagasan-gagasan dan ide-idenya.

- Memonitor, mengevaluasi, dan menunjukkan apakah pemikiran peserta didik dapat didorong secara aktif.

Dalam berbagai contoh pelaksanaan pembelajaran sejarah yang konstruktivistik tidak dapat dilepaskan dari pemanfaatan teknologi agar pengalaman belajar menjadi menarik dan mengesankan. Terkait dengan penggunaan teknologi dalam aktivitas pembelajaran yang konstruktivistik, Sharon E. Smaldino, dkk (2011: 136-137) menjelaskan bahwa peserta didik harus memiliki pengalaman dan praktik menerapkan, menganalisis, mensintesis, dan mengevaluasi ketimbang sekedar mengetahui dan memahami informasi. Belajar dalam pandangan konstruktivistik merupakan proses mental aktif yang 
dibangun berdasarkan pengalaman nyata yang relevan sehingga peserta didik akan menerima umpan balik informatif.

\section{PENUTUP}

Perubahan kurikulum tidak akan bermakna tanpa adanya perubahan dalam pelaksanaan pembelajaran. Guru sejarah harus mau membuka diri dan mengubah paradigma pemikirannya dalam kegiatan pembelajaran di sekolah agar kurikulum dapat diimplementasikan secara baik dan maksimal. Apalagi mata pelajaran sejarah dalam Kurikulum 2013 dianggap memiliki peran strategis bagi penanaman kesadaran sejarah dan nilai-nilai karakter pada peserta didik.

Kurikulum 2013 pada dasarnya berpegang pada teori konstruktivisme yang menghendaki perhatian sungguh dalam proses pembelajaran yang dilakukan peserta didik sebagai subjek belajar. Maka dalam pemikiran ini sejalan dengan tahapan-tahapan pendekatan scientific, penerapan strategi dan metode inkuiri, CTL, dan kooperatif menjadi alternatif yang dapat dilakukan oleh guru sejarah sebagai fasilitator dan motivator bagi peserta didik untuk mendapatkan pengalaman belajar yang bermakna. Seiring dengan kemajuan zaman maka pembelajaran sejarah yang konstruktivistik juga tidak dapat dilepaskan dari pemanfaatan teknologi komunikasi dan informasi.

\section{UCAPAN TERIMA KASIH}

Kami ucapkan terima kasih kepada redaksi yang telah memuat artikel ini sehingga dapat dibaca oleh kalangan akademisi secara luas. Semoga tulisan ini bermanfaat bagi perkembangan ilmu pengetahuan.

\section{DAFTAR PUSTAKA}

Aman. 2011. Model Evaluasi Pembelajaran Sejarah. Yogyakarta: Penerbit Ombak.

Kementerian Pendidikan dan Kebudayaan. 2013. Pedoman Pelatihan Implementasi Kurikulum 2013. Jakarta: Badan Pengembangan Sumber Daya Manusia Pendidikan dan Kebudayaan dan Penjaminan Mutu Pendidikan Kementerian Pendidikan dan Kebudayaan.

Hamalik, Oemar. 2011. Dasar-dasar Pengembangan Kurikulum. Bandung : PT Remaja Rosdakarya.

Ormrod, Jeanne Ellis. 2008. Psikologi Pendidikan Membantu Siswa Tumbuh dan Berkembang Edisi Keenam. Jakarta : Penerbit Erlangga.

Sanjaya, Wina. 2010. Strategi Pembelajaran Berorientasi Standar Proses Pendidikan. Jakarta : Kencana.

Santrock, John W. 2007. Psikologi Pendidikan Edisi Kedua. Jakarta : Kencana Prenada Media Group.

Schunk, Dale H. 2012. Teori-teori Pembelajaran: PerspektifPendidikan Edisi Keenam. Yogyakarta: Pustaka Pelajar.

Smaldino, Sharon E. ,dkk. 2011. Instructional Technology and Media for Learning: Teknologi Pembelajaran dan Media untuk Belajar Edisi Kesembilan. Jakarta : Kencana Prenada Media Group.

Suparno, Paul. 1997. Filsafat Konstruktivisme dalam Pendidikan. Yogyakarta: Penerbit Kanisius.

Widja,IGde.1989.Dasar-dasarPengembangan Strategi serta Metode Pengajaran Sejarah. Jakarta : Depdikbud Dirjen Dikti Proyek Pengembangan Lembaga Pendidikan Tenaga Kependidikan. 